\title{
Genetic Relationship Between Culling, Milk Production, Fertility, and Health Traits in Norwegian Red Cows
}

\author{
M. Holtsmark,,${ }^{* 1}$ B. Heringstad, ${ }^{*} \dagger$ P. Madsen, $\ddagger$ and J. Ødegård ${ }^{\star} \S$ \\ *Department of Animal and Aquacultural Sciences, Norwegian University of Life Sciences, PO Box 5003, N-1432 Ås, Norway \\ †Geno Breeding and Al Association, PO Box 5003, N-1432 Ås, Norway \\ łDepartment of Breeding and Genetics, Faculty of Agricultural Sciences, University of Århus, Research Centre Foulum, DK-8830 Tjele, Denmark \\ §AKVAFORSK, Institute of Aquaculture Research, PO Box 5010, N-1432 Ås, Norway
}

\begin{abstract}
First-lactation records on 836,452 daughters of 3,064 Norwegian Red sires were used to examine associations between culling in first lactation and 305-d protein yield, susceptibility to clinical mastitis, lactation mean somatic cell score (SCS), nonreturn rate within $56 \mathrm{~d}$ in heifers and primiparous cows, and interval from calving to first insemination. A Bayesian multivariate threshold-linear model was used for analysis. Posterior mean of heritability of liability to culling of primiparous cows was 0.04 . The posterior means of the genetic correlations between culling and the other traits were -0.41 to 305 -d protein yield, 0.20 to lactation mean SCS, 0.36 to clinical mastitis, 0.15 to interval from calving to first insemination, -0.11 to 56 -d nonreturn as heifer, and -0.04 to 56 -d nonreturn as primiparous cow. As much as $66 \%$ of the genetic variation in culling was explained by genetic variation in protein yield, clinical mastitis, interval of calving to first insemination, and 56-d nonreturn in heifers, whereas contribution from the SCS and 56-d nonreturn as primiparous cow was negligible, after taking the other traits into account. This implies that for breeds selected for a broad breeding goal, including functional traits such as health and fertility, most of the genetic variation in culling will probably be covered by other traits in the breeding goal. However, in populations where data on health and fertility is scarce or not available at all, selection against early culling may be useful in indirect selection for improved health and fertility. Regression of average sire posterior mean on birth-year of the sire indicate a genetic change equivalent to an annual decrease of the probability of culling in first-lactation Norwegian Red cattle by 0.2 percentage units. This genetic improvement is most likely a result of simultaneous selection for improved milk yield, health, and fertility over the last decades.
\end{abstract}

Received October 31, 2007.

Accepted April 28, 2008.

${ }^{1}$ Corresponding author: marte.holtsmark@umb.no
Key words: genetic correlation, culling, fertility, health

\section{INTRODUCTION}

Globally, there is an increasing interest in including longevity in dairy cattle breeding programs. Different measures of longevity have been included into the routine breeding value evaluations in many countries [e.g., Australia, Canada, Denmark, France, and United States (Interbull, 2007)]. Longevity is an important economic factor in dairy farms. The length of the life of a cow is to a large extent decided by the individual farmer through voluntary culling of low-producing animals. However, diseases, injuries, and poor fertility may also force the farmer to cull a cow. This involuntary culling will often be related to decreased animal welfare and increased costs. Decreasing involuntary culling, especially in the first lactation(s), allows the farmer to increase the voluntary culling, such that profit is maximized (van Arendonk, 1985). Hence, the aim should be to reduce involuntary culling, rather than to increase herd life, per se. One approach is to examine the functional herd life of the cows, in which the herd life is adjusted for milk production, which is considered to be the main cause of voluntary culling (Short and Lawlor, 1992; Jairath et al., 1998; Chirinos et al., 2007). Alternatively, one may select directly to improve the performance for the underlying traits causing involuntary culling.

Studies have shown positive genetic correlation between risk of culling and clinical mastitis (CM; Heringstad et al., 2003a), SCC, interval between calving and first insemination, and number of inseminations (Roxström and Strandberg, 2002). Haile-Mariam et al. (2003, 2004) found negative genetic correlations between survival in early lactations and calving interval (also shown by Olori et al., 2002), SCC, and interval from calving to first service and positive genetic correlations to nonreturn after first insemination and 6-wk pregnancy rate. Although knowledge of the genetic parameters of early culling and its genetic relation- 
Table 1. Number of cows with records of the different trait combinations: 305-d protein yield (PY305), interval from calving to first insemination (CFI), lactation mean SCS (LSCS), culling in first lactation (CULL), clinical mastitis (CM), and 56-d nonreturn for heifers (NR0) and primiparous cows (NR1)

\begin{tabular}{lccccccc}
\hline Item & PY305 & CFI & LSCS & CULL & CM & NR0 & NR1 \\
\hline PY305 & 638,893 & & & & & & \\
CFI & 510,196 & 524,268 & & & & & \\
LSCS & 638,607 & 510,083 & 638,607 & & & & \\
CULL & 637,609 & 523,610 & 637,323 & 733,487 & & & \\
CM & 638,893 & 524,268 & 638,607 & 377,487 & 735,548 & & \\
NR0 & 488,711 & 433,161 & 488,548 & 547,628 & 548,252 & 649,156 & \\
NR1 & 512,230 & 524,268 & 512,116 & 525,771 & 526,454 & 434,682 & 526,454 \\
\hline
\end{tabular}

ship with important production and functional traits is crucial for successful implementation of survival traits in the breeding objective, as well as for prediction of expected genetic improvement, few studies have been done to quantify these relationships. The aims of this study were to estimate genetic parameters for culling in first lactation, defined as a binary trait, and its genetic correlations to 305 -d protein yield, clinical mastitis, SCS, 56-d nonreturn rate in heifers and primiparous cows, and interval between calving and first insemination. Other objectives were to examine to what extent genetic variation in risk of early culling can be explained by other traits and how early culling has changed genetically over time.

\section{MATERIALS AND METHODS}

\section{Data}

Health, fertility, production, and culling data were extracted from the Norwegian Dairy Herd Recording System. The data set included 836,452 daughters of 3,064 Norwegian Red sires. Only first-crop daughters were included (difference between birth year of sire and birth year of daughter $<6 \mathrm{yr}$ ). First calving had to be between 1980 and 2004 and age at first calving between 20 and $40 \mathrm{mo}$. The data set was further restricted to cows from herd-5-yr periods with at least 5 primiparous cows.

Nonreturn rate within $56 \mathrm{~d}$ in heifers (NR0) and primiparous cows (NR1) was scored as $0=$ return or $1=$ nonreturn based on whether or not the cow had a second insemination from 6 to $56 \mathrm{~d}$ after the first insemination. A new insemination 0 to $5 \mathrm{~d}$ after an initial one was considered to be a double insemination. Clinical mastitis in the interval from $30 \mathrm{~d}$ before to $300 \mathrm{~d}$ after first calving was scored as $1=$ treated at least once and $0=$ no treatment. Interval from calving to first insemination (CFI) had to be between 20 and $210 \mathrm{~d}$. Lactation mean SCS (LSCS) and 305-d protein yield (PY305) records were calculated for cows having at least 2 test-day records. For cows with incomplete lactations, PY305 was predicted using the same procedure as used for genetic evaluation of Norwegian Red (E. Sehested, Geno Breeding and AI Association, Norway; personal communication). Culling from the herd in first lactation (CULL) was scored as 0 for cows with a recorded second calving and for cows culled later than $365 \mathrm{~d}$ after first calving, and 1 otherwise. Data were extracted more than $1 \mathrm{yr}$ after the last calving, such that all cows had the opportunity to survive up to $365 \mathrm{~d}$ after their first calving (98\% of the cows in the data set had a culling record). Using these definitions, a total of $28.5 \%$ of the cows were culled during first lactation, $19 \%$ of the cows were treated for clinical mastitis, the overall nonreturn rate was $75 \%$ for heifers and $67 \%$ for primiparous cows, and $8 \%$ of the heifers and $10 \%$ of the cows had double inseminations. The number of records for each trait and pair-wise trait combinations are given in Table 1 . The sire pedigree file had information on sires and maternal grand sires of the 3,064 sires with daughters in the data set and included a total of 3,756 males.

\section{Model}

Binary traits were analyzed using threshold models (Falconer and Mackay, 1996) postulating an underlying continuous variable, the liability $(\lambda)$, such that the observed binary response (y) takes value 0 if $\lambda$ is smaller than a threshold value (T) and 1 otherwise:

$$
y=\left\{\begin{array}{l}
0 \text { if } \lambda<\mathrm{T} \\
1 \text { if } \lambda \geq \mathrm{T}
\end{array} .\right.
$$

The 4 binary traits (NR0, NR1, CM, and CULL) and the 3 continuous traits (PY305, CFI, and LSCS), which were assumed to follow a Gaussian distribution, were analyzed using a multivariate linear-threshold sire model. In matrix notation, the model can be written as:

$$
\mathbf{Y}=\mathbf{X} \boldsymbol{\beta}+\mathbf{Z}_{1} \mathbf{h}+\mathbf{Z}_{2} \mathbf{s}+\mathbf{e}
$$


where $\mathbf{Y}$ is a vector of liabilities for the binary traits and phenotypic observations for the continuous traits;

$$
\boldsymbol{\beta}=\left[\boldsymbol{\beta}_{\mathrm{NR} 0}{ }^{\mathrm{t}} \boldsymbol{\beta}_{\mathrm{NR} 1}{ }^{\mathrm{t}} \boldsymbol{\beta}_{\mathrm{CFI}}{ }^{\mathrm{t}} \boldsymbol{\beta}_{\mathrm{CM}}{ }^{\mathrm{t}} \boldsymbol{\beta}_{\mathrm{LSCS}}{ }^{\mathrm{t}} \boldsymbol{\beta}_{\mathrm{PY} 305}{ }^{\mathrm{t}} \boldsymbol{\beta}_{\mathrm{CULL}}\right]^{\mathrm{t}},
$$

is a vector of trait-specific fixed effects, where $\boldsymbol{\beta}_{\mathrm{NR} 0}$ includes effects of double insemination (2 classes), age at first insemination (21 classes), and month-year of first insemination (316 classes) for heifers; $\boldsymbol{\beta}_{\mathrm{NR} 1}$ contains effects of double insemination, age at first calving (21 classes), and month-year of first insemination after first calving (297 classes) for cows; whereas $\boldsymbol{\beta}_{\mathrm{CFI}}, \boldsymbol{\beta}_{\mathrm{CM}}$, $\boldsymbol{\beta}_{\mathrm{LSCS}}, \boldsymbol{\beta}_{\mathrm{PY} 305}$, and $\boldsymbol{\beta}_{\mathrm{CULL}}$ include effects of age at first calving (21 classes) and month-year of first calving (288 classes); $\mathbf{h}$ is a vector of random herd-5-yr effects

$$
\mathbf{h}=\left[\mathbf{h}_{\mathrm{NR} 0}{ }^{\mathrm{t}} \mathbf{h}_{\mathrm{NR} 1}{ }^{\mathrm{t}} \mathbf{h}_{\mathrm{CFI}}{ }^{\mathrm{t}} \mathbf{h}_{\mathrm{CM}}{ }^{\mathrm{t}} \mathbf{h}_{\mathrm{LSCS}}{ }^{\mathrm{t}} \mathbf{h}_{\mathrm{PY} 305}{ }^{\mathrm{t}} \mathbf{h}_{\mathrm{CULL}}\right]^{\mathrm{t}},
$$

where $\mathbf{h}_{\mathrm{NR} 0}$ contains the random effects of the herd-5yr period of first insemination as heifer, where $\mathbf{h}_{\mathrm{NR} 1}$, $\mathbf{h}_{\mathrm{CFI}}, \mathbf{h}_{\mathrm{CM}}, \mathbf{h}_{\mathrm{LSCS}}, \mathbf{h}_{\mathrm{PY} 305}$, and $\mathbf{h}_{\mathrm{CULL}}$ contain the random herd-5-yr effects of first calving;

$$
\mathbf{s}=\left[\mathbf{s}_{\mathrm{NR} 0}{ }^{\mathrm{t}} \mathbf{S}_{\mathrm{NR} 1}{ }^{\mathrm{t}} \mathbf{S}_{\mathrm{CFI}}{ }^{\mathrm{t}} \mathbf{S}_{\mathrm{CM}}{ }^{\mathrm{t}} \mathbf{S}_{\mathrm{LSCS}}{ }^{\mathrm{t}} \mathbf{S}_{\mathrm{PY} 305}{ }^{\mathrm{t}} \mathbf{S}_{\mathrm{CULL}}{ }^{\mathrm{t}}\right]^{\mathrm{t}},
$$

is a vector of sire effects; $\mathbf{e}$ is a vector of random residuals; and $\mathbf{X}, \mathbf{Z}_{1}$, and $\mathbf{Z}_{2}$ are the corresponding incidence matrices.

Residuals were assumed independent between cows and correlated across traits within cow, following a multivariate normal distribution, $\mathbf{e} \sim \mathrm{N}(0, \mathbf{R} \otimes \mathrm{I})$, where $\mathbf{R}$ is the residual (co)variance matrix for the 7 traits. For all binary traits, residual variances (in the liability scale) were set equal to 1 (Sorensen and Gianola, 2002). The residual (co)variance matrix was sampled using the approach of Korsgaard et al. (2005), combining the findings of Korsgaard et al. (2003) and González (2004), imposing restrictions on the residual variances of the liabilities for the binary traits.

Prior Distributions. Independent bounded uniform priors were assumed for each of the fixed effects. Multivariate normal prior distributions were assigned for sire and herd-5-yr effects:

$$
\mathbf{s} \mid \mathbf{A}, \mathbf{G}_{\mathbf{0}} \sim \mathrm{N}\left(0, \mathbf{G}_{\mathbf{0}} \otimes \mathbf{A}\right) \text {, and } \mathbf{h} \mid \mathbf{H}_{\mathbf{0}} \sim \mathrm{N}\left(0, \mathbf{H}_{\mathbf{0}} \otimes \mathbf{I}\right),
$$

respectively, where $\mathbf{G}_{\mathbf{0}}$ and $\mathbf{H}_{\mathbf{0}}$ are the $7 \times 7$ (co)variance matrices for sire and herd-5-yr effects, $\mathrm{A}$ is the additive genetic relationship matrix of the 3,756 sires, and $\mathbf{I}$ is an identity matrix with rank equal to number of herd-5-yr classes $(69,798)$. The matrices $\mathbf{G}_{0}, \mathbf{H}_{0}$, and $\mathbf{R}$ were required to be positive definite.

Sampling and Convergence Diagnostics. The data were analyzed using Gibbs sampling in the RJMC routine of the DMU software (Madsen and Jensen, 2006). One chain with a total of 40,000 rounds, with samples stored at every 10th round, was evaluated with the Raftery and Lewis convergence diagnostics (Raftery and Lewis, 1992) using the BOA software package (Smith, 2005). To estimate the $2.5 \%$ quantile of each parameter to within \pm 0.005 with $95 \%$ probability, a chain of 290,000 iterations (saving every 10th round) was required. To achieve this, the original chain was prolonged to 85,000 samples (after discarding the first 20,000 as burn-in). In addition, 3 independent chains, each consisting of 76,000 samples, were branched out from the original chain. Independence of the chains was assured by changing random seed numbers for the random number generators and by excluding the first 1,000 rounds of each chain as an additional burn-in. Posterior means were calculated across all chains. Within each round of sampling, heritabilities were calculated as $h^{2}=4 \sigma_{S}^{2} /\left(\sigma_{S}^{2}+\sigma_{E}^{2}\right)$, where $\sigma_{S}^{2}$ and $\sigma_{E}^{2}$ are the estimated sire and the residual variances, respectively.

\section{Sire Evaluation and Genetic Change}

The posterior means of sire-transmitting abilities for CULL were transformed from the liability scale to the probability scale using:

$$
\mathrm{p}_{i}=\Phi\left(\mu+\bar{s}_{i}\right)
$$

where $\mathrm{p}_{i}$ is the expected probability of culling in first lactation for daughters of sire $\mathrm{i}, \mu$ is the overall mean liability of CULL, and $\bar{s}_{i}$ is the posterior mean of sire $i$. Genetic change for CULL was evaluated by plotting average sire posterior means against birth-year of the sire. The average annual change was estimated as the slope of the corresponding linear regression.

\section{Amount of Genetic Variance for Culling Explained by Other Traits}

Health, fertility, and production traits influence culling decisions. The relative amount of genetic variation in CULL that can be explained by genetic variation in the other traits included in our study was examined through Cholesky decomposition of the posterior mean of the genetic correlation matrix (with CULL as the last trait in the matrix). The proportion of free genetic variation in liability of CULL is then the square of the last diagonal element of the resulting matrix $\mathbf{L}\left(\mathbf{L}_{77}^{2}\right)$ (i.e., the proportion of genetic variance not explained by other traits). 
Table 2. Posterior mean (standard deviation) of within-herd heritability $\left(\mathrm{h}^{2}\right)$, sire variance (on the diagonal), sire covariance (above the diagonal), and genetic correlations (below the diagonal) between 305-d protein yield (PY305), interval from calving to first insemination (CFI), lactation mean SCS (LSCS), culling in first lactation (CULL), clinical mastitis (CM), and 56-d nonreturn for heifers (NR0) and primiparous cows (NR1)

\begin{tabular}{lcccccccc}
\hline Item & PY305 & CFI & LSCS & CULL & CM & NR0 & NR1 & $\mathrm{h}^{2}$ \\
\hline PY305 & 32.908 & 6.142 & 0.109 & -0.235 & 0.265 & -0.025 & -0.090 & 0.20 \\
& $(0.986)$ & $(0.398)$ & $(0.020)$ & $(0.017)$ & $(0.021)$ & $(0.015)$ & $(0.015)$ & $(0.006)$ \\
CFI & 0.48 & 5.052 & 0.028 & 0.034 & 0.088 & 0.043 & 0.006 & 0.03 \\
& $(0.03)$ & $(0.278)$ & $(0.011)$ & $(0.009)$ & $(0.011)$ & $(0.007)$ & $(0.008)$ & $(0.002)$ \\
LSCS & 0.12 & 0.08 & 0.026 & 0.003 & 0.011 & 0.000 & -0.001 & 0.12 \\
& $(0.02)$ & $(0.03)$ & $(0.001)$ & $(0.000)$ & $(0.001)$ & $(0.000)$ & $(0.000)$ & $(0.004)$ \\
CULL & -0.41 & 0.15 & 0.20 & 0.010 & 0.005 & -0.001 & 0.000 & 0.04 \\
& $(0.02)$ & $(0.04)$ & $(0.02)$ & $(0.001)$ & $(0.000)$ & $(0.000)$ & $(0.000)$ & $(0.002)$ \\
CM & 0.34 & 0.28 & 0.50 & 0.36 & 0.019 & 0.000 & -0.000 & 0.07 \\
& $(0.02)$ & $(0.03)$ & $(0.02)$ & $(0.03)$ & $(0.001)$ & $(0.000)$ & $(0.000)$ & $(0.003)$ \\
NR0 & -0.07 & 0.29 & -0.03 & -0.11 & 0.05 & 0.004 & 0.003 & 0.02 \\
& $(0.04)$ & $(0.05)$ & $(0.04)$ & $(0.05)$ & $(0.04)$ & $(0.000)$ & $(0.000)$ & $(0.001)$ \\
NR1 & -0.24 & 0.04 & -0.14 & -0.04 & -0.04 & 0.61 & 0.004 & 0.02 \\
& $(0.04)$ & $(0.05)$ & $(0.04)$ & $(0.05)$ & $(0.05)$ & $(0.06)$ & $(0.000)$ & $(0.002)$ \\
\hline
\end{tabular}

\section{RESULTS AND DISCUSSION}

\section{Heritability}

The posterior distributions of the heritabilities were all sharp and symmetric (results not shown). The posterior mean (SD) of heritability of liability to CULL was 0.04 (0.002; Table 2). This point estimate was somewhat greater than the threshold model estimate of Heringstad et al. (2003a) of 0.02. Applying a linear sire model, Nielsen et al. (1999) found a heritability of 0.04 to 0.07 for survival from first calving to the end of the second lactation (binary trait). Also applying linear models, Jairath et al. (1998) estimated a heritability of 0.03 for functional survival in the first lactation, whereas Olori et al. (2002) estimated the heritability for survival in first lactation, preadjusted for milk yield, to be 0.01 . Because heritability estimates from linear models are frequency dependent and may vary with the trait definition, the latter estimates are not directly comparable to the estimates obtained in our study. The heritabilities for the other traits (Table 2) showed good agreement with estimates from several previous studies on Norwegian Red (with partly overlapping data sets, e.g., Heringstad et al. (2003b); Ødegård et al. (2004); Andersen-Ranberg et al. (2005a,b); Andersen-Ranberg and Heringstad (2006).

\section{Genetic Correlations}

As shown in Table 2, the posterior means of the genetic correlations between CULL and the other traits were greatest for PY305 and CM, -0.41 and 0.36 , respectively, followed by LSCS, CFI, NR0, and NR1. The genetic correlation between NR1 and CULL was not significantly different from 0.0 (23.7\% of the samples

Table 3. Posterior mean (standard deviation) of herd-5-yr variance (on the diagonal), herd-5-yr covariance (above the diagonal), and herd-5-yr correlations (below the diagonal) between 305-d protein yield (PY305), interval from calving to first insemination (CFI), lactation mean SCS (LSCS), culling in the first lactation (CULL), clinical mastitis (CM), and 56-d nonreturn for heifers (NR0) and primiparous cows (NR1)

\begin{tabular}{lccccccc}
\hline Item & PY305 & CFI & LSCS & CULL & CM & NR0 & NR1 \\
\hline PY305 & 374.261 & -4.720 & -0.067 & 0.174 & 1.366 & -0.113 & -0.635 \\
& $(2.455)$ & $(1.257)$ & $(0.032)$ & $(0.042)$ & $(0.050)$ & $(0.044)$ & $(0.044)$ \\
CFI & -0.022 & 121.899 & 0.082 & -0.598 & -0.245 & 0.860 & 1.408 \\
& $(0.006)$ & $(1.264)$ & $(0.022)$ & $(0.030)$ & $(0.035)$ & $(0.031)$ & $(0.032)$ \\
LSCS & -0.014 & 0.031 & 0.058 & 0.001 & -0.008 & 0.003 & 0.004 \\
& $(0.007)$ & $(0.009)$ & $(0.001)$ & $(0.001)$ & $(0.001)$ & $(0.001)$ & $(0.001)$ \\
CULL & 0.032 & -0.194 & 0.016 & 0.078 & -0.004 & 0.000 & -0.005 \\
& $(0.008)$ & $(0.010)$ & $(0.011)$ & $(0.002)$ & $(0.001)$ & $(0.001)$ & $(0.001)$ \\
CM & 0.191 & -0.060 & -0.088 & -0.038 & 0.136 & -0.010 & -0.017 \\
& $(0.007)$ & $(0.009)$ & $(0.010)$ & $(0.012)$ & $(0.002)$ & $(0.001)$ & $(0.001)$ \\
NR0 & -0.035 & 0.464 & 0.074 & 0.003 & -0.166 & 0.028 & 0.028 \\
& $(0.013)$ & $(0.017)$ & $(0.019)$ & $(0.021)$ & $(0.019)$ & $(0.001)$ & $(0.001)$ \\
NR1 & -0.147 & 0.571 & 0.074 & -0.085 & -0.202 & 0.748 & 0.050 \\
& $(0.010)$ & $(0.012)$ & $(0.015)$ & $(0.016)$ & $(0.015)$ & $(0.027)$ & $(0.002)$ \\
\hline
\end{tabular}


Table 4. Posterior mean (standard deviation) of residual variance (on the diagonal), residual covariance (above the diagonal), and residual correlations (below the diagonal) between 305-d protein yield (PY305), interval from calving to first insemination (CFI), lactation mean SCS (LSCS), culling in first lactation (CULL), clinical mastitis (CM), and 56-d nonreturn for heifers (NR0) and primiparous cows (NR1)

\begin{tabular}{lccccccc}
\hline Item & PY305 & CFI & LSCS & CULL & CM & NR0 & NR1 \\
\hline PY305 & 625.928 & 43.272 & -1.707 & -4.186 & -0.318 & -0.073 & -1.024 \\
& $(1.158)$ & $(0.889)$ & $(0.030)$ & $(0.039)$ & $(0.044)$ & $(0.040)$ & $(0.038)$ \\
CFI & 0.065 & 697.795 & -0.235 & 0.146 & 0.053 & 1.060 & 2.276 \\
& $(0.001)$ & $(1.428)$ & $(0.032)$ & $(0.043)$ & $(0.045)$ & $(0.042)$ & $(0.048)$ \\
LSCS & -0.076 & -0.010 & 0.806 & 0.074 & 0.089 & -0.004 & 0.003 \\
& $(0.001)$ & $(0.001)$ & $(0.002)$ & $(0.001)$ & $(0.002)$ & $(0.001)$ & $(0.001)$ \\
CULL & -0.167 & 0.006 & 0.083 & 1.000 & 0.136 & -0.005 & -0.035 \\
& $(0.002)$ & $(0.002)$ & $(0.002)$ & & $(0.002)$ & $(0.002)$ & $(0.002)$ \\
CM & -0.013 & 0.002 & 0.099 & 0.136 & 1.000 & -0.005 & 0.004 \\
& $(0.002)$ & $(0.002)$ & $(0.002)$ & $(0.002)$ & & $(0.002)$ & $(0.002)$ \\
NR0 & -0.003 & 0.040 & -0.005 & -0.005 & -0.005 & 1.000 & 0.012 \\
& $(0.002)$ & $(0.002)$ & $(0.002)$ & $(0.002)$ & $(0.002)$ & & $(0.002)$ \\
NR1 & -0.041 & 0.086 & 0.003 & -0.035 & 0.004 & 0.012 & 1.000 \\
& $(0.002)$ & $(0.002)$ & $(0.002)$ & $(0.002)$ & $(0.002)$ & $(0.002)$ & \\
\hline
\end{tabular}

were equal or greater than 0.0). Table 2 shows a weak negative correlation between CULL and NR0 and a weak positive genetic correlation between CULL and CFI. The latter is in agreement with Haile-Mariam et al. (2004), who found a genetic correlation of -0.10 between survival in first lactation (the opposite of culling) and interval from calving to first service. The weak correlation between CULL and CFI may be explained by farmers deciding to cull cows that come very late into heat after first calving, rather than inseminating them. This would result in missing data for CFI and NR1 and cause selection in data for interval from calving to first heat, which is not accounted for as long as CFI is missing. Hence, the cows with the longest interval from calving to first heat (not recorded) are likely to be overrepresented among the cows with missing observations and may potentially cause some bias in estimates of some genetic correlations.

Table 2 shows a moderate, negative genetic correlation between CULL and PY305 of -0.41 and moderate positive genetic correlations of CULL with CM of 0.36 and LSCS of 0.20. Heringstad et al. (2003a) also found a moderate genetic correlation of 0.53 between CULL and CM when analyzing a smaller data set from the same breed. Nielsen et al. (1999) reported genetic correlations ranging from -0.37 to -0.75 between survival (the opposite of culling) and udder disease in first lactation for Danish Red, Danish Holstein, and Danish Jersey. Short and Lawlor (1992) found a genetic correlation between 305-d milk yield in first lactation (a trait strongly correlated with PY305) and occurrence of a second calving (the opposite of CULL) of 0.33 , which is similar to our estimated correlation between CULL and PY305.

The moderate to small, unfavorable genetic correlations between PY305 and the health and fertility traits
(Table 2) were in agreement with previous studies (Carlén et al., 2004; Heringstad et al., 2005; AndersenRanberg and Heringstad, 2006). The estimated genetic correlations within and between the fertility and health traits (Table 2) were all similar to estimates from previous studies in Norwegian Red (Ødegård et al., 2004; Andersen-Ranberg et al., 2005a,b; Andersen-Ranberg and Heringstad, 2006).

\section{Herd 5-Yr and Residual Correlations}

The herd-5-yr and residual correlations are given in Tables 3 and 4, respectively. Most herd-5-yr correlations were small, except for NR0 and NR1, CFI and NR1, and CFI and NR0, which were moderate. These correlations show that, as expected, herd-management effect fertility. Residual correlations between traits were generally close to 0 , except the correlations between PY305 and CULL and CM and CULL, which were small.

\section{Genetic Change in Culling of Primiparous Cows}

Average sire posterior mean for probability of culling by birth-year of sire is given in Figure 1. The figure shows a steady decrease of the sire posterior means for probability of culling of primiparous cows by $0.2 \%$ units per year, which is likely to be a result of genetic improvement of milk yield, health, and fertility in Norwegian Red as a result of selection for a broad breeding goal (Geno, 2007). However, as observed by van Arendonk (1985), the reduction of involuntary culling may not increase the productive herd life of the cows, because the farmer may increase the rate of voluntary culling. This may especially occur when the carcass value approaches the cost of raising a replacement 


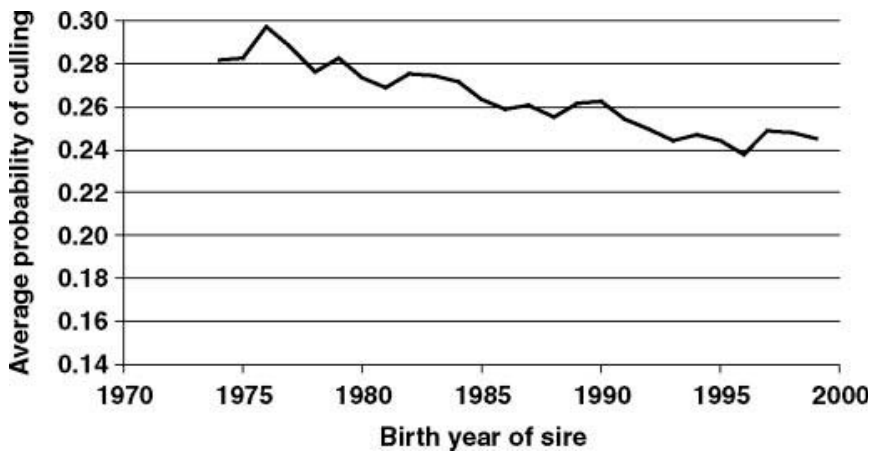

Figure 1. Average sire posterior mean for probability of culling by birth year of sire.

heifer (Allaire and Cunningham, 1980; van Arendonk, 1985). Norwegian Red is selected for both milk and beef production, and because most Norwegian dairy farmers use the Norwegian Red both for milk and beef production, this affects the rate of voluntary culling.

\section{Genetic Variation in Culling Can Be Explained by Other Traits}

A Cholesky decomposition of the genetic correlation matrix (Table 2 ) revealed that $66 \%$ of the genetic variation for CULL was explained by genetic variation in PY305, CM, CFI, and NR0. The traits NR1 and LSCS had no significant effect on genetic variation in liability of CULL that was not already explained by the other traits. Examining first-lactation health and survival data in Danish dairy breeds, Nielsen et al. (1999) found that survival had moderate to high genetic correlations with udder diseases, ranging from -0.37 to -0.75 , and feet and leg diseases, ranging from -0.42 to -0.43 . It was concluded that although the frequency of feet and leg diseases in the material was low, these diseases tended to cripple the cows and therefore often resulted in culling. Although the major part of the genetic variation in liability to culling in Norwegian Red is explained by traits that are included in the current study, there are also several other traits that may be of some importance for genetic variation in liability to early culling (e.g., other diseases, conformation traits, and temperament) that are currently included in the breeding program for Norwegian Red (Geno, 2007).

Generally, including information on a correlated trait will usually improve accuracy of selection. However, this is not the case if the new trait is a function of the formerly included traits (e.g., protein percentage in addition to milk and protein yield). For early culling, phenotypes of the underlying traits are often direct causes of both voluntary and involuntary culling (e.g., poor milk yield, health, fertility, or a combination of those). Thus, for breeding programs in which the most important of these factors are directly recorded and selected for, there is most likely little to gain by including data on early culling in genetic evaluation. However, all costs associated with each underlying trait, including the risk of involuntary culling, should be taken into account in calculation of their economical values. For dairy cattle populations in which registration of health or fertility traits, or both, are less comprehensive, information on early culling, which may be rather easy to obtain, could be useful in indirect selection for improvement of the underlying traits.

\section{CONCLUSIONS}

As much as $66 \%$ of the genetic variation in culling in primiparous cows can be explained by genetic variation in protein yield, clinical mastitis, and fertility (CFI, and nonreturn in heifers). Further research is needed to examine whether there will be any additional value of including early culling in selection programs that already have direct selection on health, fertility, and production traits. However, for populations in which direct information on health and fertility traits is scarce, early culling may be a useful tool for indirect selection for improved health and fertility.

\section{ACKNOWLEDGMENTS}

Access to the data was granted by the Norwegian Dairy Herd Recording System in agreement no. 005/2006. This study is a part of the project "Selection for reduced risk of early culling in dairy cattle: Comparison of alternative approaches to improve animal welfare" (project no. 173276/I10), financed by the Research Council of Norway.

\section{REFERENCES}

Allaire, F. R., and E. P. Cunningham. 1980. Culling on low milk yield and its economic consequences for the dairy herd. Livest. Prod. Sci. 7:349-359.

Andersen-Ranberg, I. M., and B. Heringstad. 2006. Genetic associations between female fertility, mastitis and protein yield in Norwegian Red. Proc. 8th World Congr. Genet. Appl. Livest. Prod., Belo Horizonte, Brazil. Commun. No. 1-20.

Andersen-Ranberg, I. M., B. Heringstad, D. Gianola, Y. M. Chang, and G. Klemetsdal. 2005a. Comparison between bivariate models for 56-day nonreturn and interval from calving to first lactation in Norwegian Red. J. Dairy Sci. 88:2190-2198.

Andersen-Ranberg, I. M., G. Klemetsdal, B. Heringstad, and T. Steine. 2005b. Heritabilities, genetic correlations, and genetic change for female fertility and protein yield in Norwegian dairy cattle. J. Dairy Sci. 88:348-355.

Carlén, E., E. Strandberg, and A. Roth. 2004. Genetic parameters for clinical mastitis, SCS, and production in the first three lactations of Swedish Holstein cows. J. Dairy Sci. 87:3062-3070.

Chirinos, Z., M. J. Carabaño, and D. Hernández. 2007. Genetic evaluation of length of productive life in the Spanish Holstein 
Friesian population. Model validation and genetic parameters estimation. Livest. Prod. Sci. 106:120-131.

Falconer, D. S., and T. F. C. Mackay. 1996. Introduction to Quantitative Genetics. 4th ed. Addison Wesley Longman Ltd., Essex, UK.

Geno. 2007. Net merit index. http://www.geno.no/ Accessed July 2007.

González, L. G. 2004. Data augmentation in the Bayesian multivariate probit model. Discussion paper SERP2004001 (PDF), University of Sheffield. http://www.shef.ac.uk/content/1/ c6/06/31/58/SERP2004001.pdf Accessed July 2007.

Haile-Mariam, M., P. J. Bowman, and M. E. Goddard. 2003. Genetic and environmental relationship among calving interval, survival, persistency of milk yield and SCC in dairy cattle. Livest. Prod. Sci. 80:189-200.

Haile-Mariam, M., P. J. Bowman, and M. E. Goddard. 2004 Genetic parameters of fertility traits and their correlations with production, type, workability, liveweight, survival index and cell count. Aust. J. Agric. Res. 55:77-87.

Heringstad, B., Y. M. Chang, D. Gianola, and G. Klemetsdal. 2005. Genetic associations between susceptibility to clinical mastitis and protein yield in Norwegian dairy cattle. J. Dairy Sci. 88:1509-1514.

Heringstad, B., R. Rekaya, D. Gianola, G. Klemetsdal, and K. A. Weigel. 2003a. Bivariate analysis of liability to clinical mastitis and to culling in first lactation cows. J. Dairy Sci. 86:653-660.

Heringstad, B., R. Rekaya, D. Gianola, G. Klemetsdal, and K. A Weigel. 2003b. Genetic change for clinical mastitis in Norwegian Cattle: A threshold model analysis. J. Dairy Sci. 86:369-375.

Interbull. 2007. Description of National Genetic Evaluation Systems for dairy cattle traits as applied in different Interbull member countries. http://www-interbull.slu.se/national_ges_info2/ framesida-ges.htm Accessed July 2007.

Jairath, L., J. C. M. Dekkers, L. R. Schaeffer, Z. Liu, E. B. Burnside, and B. Kolstad. 1998. Genetic evaluation for herd life in Canada. J. Dairy Sci. 81:550-562.

Korsgaard, I. R., A. H. Andersen, P. Madsen, and J. Ødegård. 2005. Another useful reparameterisation to obtain samples from conditional inverse Wishart distributions. I: Proc. EAAP, Book of abstracts 11. Wageningen Pers, Wageningen, the Netherlands.
Korsgaard, I. R., M. Sandø Lund, D. Sorensen, D. Gianola, P. Madsen, and J. Jensen. 2003. Multivariate Bayesian analysis of Gaussian, right censored Gaussian, ordered categorical and binary traits using Gibbs sampling. Genet. Sel. Evol. 35:159-183.

Madsen, P., and J. Jensen. 2006. A User's Guide to DMU. A Package for Analysing Multivariate Mixed Models. Version 6, release 4.6 Danish Institute of Agricultural Sciences, Tjele, Denmark.

Nielsen, U. S., G. A. Pedersen, J. Pedersen, and J. Jensen. 1999. Genetic variation in disease traits and their relationship with survival in Danish dairy cattle. Interbull Bull. 21:170-178.

Ødegård, J., B. Heringstad, and G. Klemetsdal. 2004. Short communication: Bivariate genetic analysis of clinical mastitis and SCC in Norwegian dairy cattle. J. Dairy Sci. 87:3515-3517.

Olori, V. E., T. H. E. Meuwissen, and R. F. Veerkamp. 2002. Calving interval and survival breeding values as measure of cow fertility in a pasture-based production system with seasonal calving. J. Dairy Sci. 85:689-696.

Raftery, A. L., and S. Lewis. 1992. How many iterations in the Gibbs sampler? Pages 763-774 in Bayesian Statistics 4. J. M. Bernardo, J. O. Berger, A. P. Dawid, and A. F. M. Smith, ed. Oxford University Press, Oxford, UK.

Roxström, A., and E. Strandberg. 2002. Genetic analysis of functional fertility-, mastitis-, and production-determined length of productive life in Swedish dairy cattle. Livest. Prod. Sci $74: 125-135$.

Short, T. H., and T. J. Lawlor. 1992. Genetic parameters of conformation traits, milk yield, and herd life in Holsteins. J. Dairy Sci. 75:1987-1998.

Smith, B. J. 2005. Bayesian output analysis program (BOA), version 1.1. Users manual. http://www.public-health.uiowa.edu/boa/ BOA.pdf Accessed July 2007.

Sorensen, D., and D. Gianola. 2002. Likelihood, Bayesian, and MCMC methods in quantitative genetics. Springer-Verlag, New York, NY.

van Arendonk, J. A. M. 1985. Studies on the replacement policies in dairy cattle. II. Optimum policy and influence of changes in production and prices. Livest. Prod. Sci. 13:101-121. 